\title{
Efek Waktu Pemberian Pakan dan Level Energi terhadap Cekaman Panas Berdasarkan Suhu Rektal dan Kulit Sapi Dara Fries Holland
}

\author{
Effect of Feeding Time and Energy Level on Heat Stress Based on Rectal and Skin \\ Temperature of Fries Holland Heifer
}

\author{
Dadang Suherman \\ Jurusan Peternakan, Fakultas Pertanian Universitas Bengkulu \\ Jalan Raya Kandang Limun, Bengkulu. Telp. (0736) 21170 pst.219 \\ Email:dadangsuherman707@yahoo.com
}

\begin{abstract}
The objective of this research was to evaluate rectal and skin temperature of dairy heifers on feeding time. Six dairy heifers were randomly allocated to 1 of 6 treatments: P1 (feeding time $5 \mathrm{am} / 6 \mathrm{pm}$ ), P2 (feeding time 8 am/4 pm) and R1 (TDN 70\%), R2 (TDN 75\%), R3 (TDN 75\% supplemented with 3,5\% coconut oil). Thus, 6 treatments were P1R1 (A), P1R2 (B), P1R3 (C), P2R1 (D), P2R2 (E), P2R3 (F), in each of periods of 14 d each in a 6 x 6 Latin Square Design. The environmental conditions (air temperature, relative humidity, temperature humidity index, radiation, and wind velocity) and animal responses (rectal temperature and skin temperature). The environmental conditions were measured daily at $1 \mathrm{~h}$ intervals from $5 \mathrm{am}$ to $8 \mathrm{pm}$. The animals responses were measured at the $4^{\text {th }}, 8^{\text {th }}, 12^{\text {th }}, 14^{\text {th }}$, day of each periode at $1 \mathrm{~h}$ intervals from 5 am to 8 pm. Tukey's test and contrast orthogonal analyses were used. The results showed that rectal and skin temperature were significantly lower on cattle which fed at 5 am and $6 \mathrm{pm}$ than that of 8 am and $4 \mathrm{pm}$. The conclusion was heat stress of dairy heifer could be reduced by managing feeding time and feeding with easily digestible nutrient.
\end{abstract}

Keywords: Feeding time, rectal temperature, skin temperature, heifer

\begin{abstract}
ABSTRAK
Tujuan penelitian ini untuk mengevaluasi respon suhu rektal dan kulit sapi dara FH pada waktu pemberian pakan berbeda yang diberi konsentrat dengan kandungan TDN berbeda pula. Enam perlakuan: P1 (waktu pemberian pakan pukul 5.00 \& 18.00), P2 (pukul $8.00 \& 16.00$ ) dan R1 (level TDN konsentrat 70\%), R2 (level TDN konsentrat 75\%), R3 (TDN konsentrat 75\% mengandung minyak kelapa 3,5\%). Secara keseluruhan, enam perlakuan: P1R1 (A), P1R2 (B), P1R3 (C), P2R1 (D), P2R2 (E), dan P2R3 (F). Penelitian dilakukan selama enam periode dan setiap periode selama 14 hari. Pengambilan data dilakukan setiap jam pada hari ke $4,8,12$, dan 14 dari pukul 05.00 hingga pukul 20.00. Parameter unsur cuaca (suhu udara, kelembaban udara, kecepatan angin, dan radiasi matahari), parameter respon fisiologias (suhu rektal dan suhu kulit). Rancangan digunakan Rancangan Bujur Sangkar Latin 6 x 6. Analisis lanjut menggunakan Uji Tukey dan Kontras Ortogonal. Hasil penelitian didapatkan bahwa ternak yang mengkonsumsi pakan pada pukul 05.00 dan 18.00 cenderung memiliki rataan respon suhu rektal dan suhu kulit lebih rendah saat ada cekaman panas siang hari. Kesimpulan dari penelitian ini adalah beban cekaman panas dari sapi dara dapat diatasi dengan pengaturan waktu pemberian pakan dan pemberian pakan dengan energi mudah dicerna.
\end{abstract}

Kata kunci: Waktu pemberian pakan, suhu rektal, suhu kulit, sapi perah dara

\section{PENDAHULUAN}

Manajemen cuaca lingkungan dapat diterapkan melalui pengaturan waktu pemberian pakan yang tepat berdasarkan cuaca lingkungan yang sesuai. Manajemen pakan dan cuaca lingkungan berfungsi agar produksi dan pelepasan panas tubuh seimbang. Keseimbangan panas tersebut, syarat untuk mencapai kondisi fisiologi dan produktivitas ternak yang optimal. Keseimbangan panas tubuh dapat dipengaruhi kondisi internal dan eksternal tubuh. Kondisi eksternal yang menjadi kendala terutama adalah suhu udara, kelembaban udara, kecepatan angin, dan 
radiasi matahari (Purwanto et al., 1993 ${ }^{\mathrm{a}}$ ).

Kondisi internal tubuh adalah prosesproses fisiologis berupa suhu rektal dan suhu kulit, termasuk proses metabolisme pakan.

Hasil penelitian Purwanto et al. $\left(1993^{b}\right)$ menunjukan bahwa produksi panas tubuh mencapai maksimal dan frekuensi suhu rektal dan denyut jantung tertinggi terjadi saat tiga jam setelah pemberian pakan. Modifikasi waktu pemberian pakan dilakukan dengan cara memberi pakan tiga jam lebih awal dari waktu yang biasa dilakukan, agar tidak terjadi double stress. Penelitian ini dilakukan dengan tujuan untuk mengetahui pengaruh modifikasi waktu pemberian pakan dalam mengurangi beban panas ganda/double strees, artinya beban panas hasil metabolisme pakan terjadi bersamaan dengan beban panas dari lingkungan.

Selain mengatur waktu pemberian pakan, usaha mengurangi beban panas pada ternak dapat dilakukan pula dengan mengatur komposisi pakan. Pengaturan komposisi pakan merupakan cara yang efektif untuk mengurangi hilangnya nutrisi pakan ke lingkungan (Van Der Steit et al., 2008). Minyak kelapa dapat digunakan sebagai sumber energi pakan ternak cukup baik pada lingkungan yang berpotensi memberikan cekaman panas. Peranan minyak kelapa pada pakan sebagai sumber energi melalui konversi gliserol yang terbebaskan dari proses hidrolisis lemak menjadi VFA. Kombinasi penggunaan minyak kelapa dan waktu pemberian pakan diharapkan dapat membantu tubuh ternak tetap normal pada lingkungan yang berpotensi membrikan cekaman panas.
Penelitian bertujuan untuk mengevaluasi respon suhu rektal dan suhu kulit sapi dara Fries Holland pada waktu pemberian pakan berbeda yang diberi konsentrat dengan kandungan TDN berbeda pula, serta diharapkan dapat membantu tubuh ternak normal pada lingkungan yang berpotensi memberikan cekaman panas.

\section{MATERI DAN METODE}

Waktu penelitian dibagi menjadi enam periode, masing-masing periode perlakuan selama 14 hari. Penelitian dilaksanakan di kandang ternak perah, Departemen Ilmu Produksi dan Teknologi Peternakan, Fakultas Peternakan, Kampus IPB Dramaga.

Bangsa sapi dara Fries Holland sebanyak enam ekor, bobot badan pada awal penelitian berkisar antara 170-276 kg. Pemandian sapi dilakukan siang hari pada akhir setiap periode perlakuan. Pakan digunakan rumput gajah dan konsentrat dengan rasio 60:40. Waktu pemberian pakan terdiri atas pemberian pakan pada pukul 05.00 dan 18.00 (P1) dan pukul 08.00 dan 16.00 (P2). Konsentrat terdiri dari tiga jenis, yaitu konsentrat dengan TDN 70\% (R1), TDN 75\% (R2), dan TDN $75 \%$ yang mengandung minyak kelapa 3,5\% (R3). Pemberian bahan kering pakan sebanyak 2,5\% dari bobot badan hidup (NRC, 2001). Komposisi bahan pakan dan nutrisi ransum dapat dilihat pada Tabel 1.

Penelitian dilaksanakan selama enam periode dengan enam perlakuan. Enam kombinasi perlakuan dari waktu pemberian pakan dan jenis konsentrat, yaitu P1R1 
(A), P1R2 (B), P1R3 (C), P2R1 (D), P2R2

(E), dan P2R3 (F). Setiap kombinasi perlakukan menggunakan satu ekor sapi dara. Penelitian menggunakan Rancangan Bujur Sangkar Latin (RBSL).

Kandang digunakan berbentuk monitor dengan setiap individu sapi menempati tiap petak kandang ukuran $1 \mathrm{x}$ $1,8 \mathrm{~m}$, tinggi kandang $4 \mathrm{~m}$, tinggi ke monitor kandang $5 \mathrm{~m}$, dan atap asbes. Peralatan penelitian digunakan yaitu termometer rektal, termometer pengukur suhu kulit digital, stetoskop, termometer bola kering dan bola basah, lux meter, dan anemometer digital.

Variabel yang diamati terdiri atas iklim mikro dan respon fisiologis. Faktor iklim mikro yang diukur meliputi suhu udara $\left(\mathrm{T}_{\mathrm{db}}\right)$, kelembaban udara $(\mathrm{RH})$, Temperature humidity index (THI), radiasi matahari $\left(\mathrm{R}_{\mathrm{ad}}\right)$, dan kecepatan angin. Respon fisiologis sapi dara diukur adalah suhu rektal (rT), suhu kulit (sT), dan suhu tubuh (bT). Pengukuran konsumsi pakan dan pertambahan bobot badan. Pengukuran iklim mikro, respon suhu rektal dan suhu kulit, dan konsumsi pakan dan pertambahan bobot badan diamati hari ke-
4, 8, 12, dan ke-14 setiap periode, pada setiap hari pengamatan dilakukan dari pukul 05.00 hingga 20.00.

Pengukuran suhu dan kelembaban udara di dalam kandang menggunakan termometer bola basah dan bola kering. Indeks suhu kelembaban (THI) mengacu pada Hann (1985) yaitu; THI = DBT + 0,36WBT $+41,2 . \mathrm{DBT}=$ suhu bola kering $\left({ }^{0} \mathrm{C}\right)$ dan $\mathrm{WBT}=$ suhu bola basah $\left({ }^{0} \mathrm{C}\right)$. Radiasi matahari diukur menggunakan lux meter (lux). Kecepatan angin dikukur menggunakan anemometer digital diletakkan di sisi tempat ventilasi kandang selama 3 menit (m/detik). Suhu rektal diukur dengan memasukkan termometer klinis ke dalam rektal sedalam $10 \mathrm{~cm}$ selama 1,5 menit. Suhu kulit diukur di empat titik lokasi pengukuran yaitu punggung (A), dada (B), tungkai atas (C), dan tungkai bawah (D). Rataan suhu kulit dihitung berdasarkan rumus Mc Lean et al. (1983); sT = 0,25 (A + B ) + 0,32 C + 0,18 D. Suhu tubuh (bT) dihitung dari suhu kulit (sT) dan suhu rektal (rT) menurut Mc Lean et al. (1983); bT =0,86 rT + 0,14 sT.

Tabel 1 Komposisi dan kandungan pakan penelitian (\%)

\begin{tabular}{lccc}
\hline Bahan Pakan & $\mathrm{R}_{1}$ & $\mathrm{R}_{2}$ & $\mathrm{R}_{3}$ \\
\hline Dedak & 33,77 & 13,82 & 32,03 \\
Jagung & 8,98 & 15,46 & 7,08 \\
Polard & 29,37 & 14,56 & 26,78 \\
Onggok & 18,26 & 26,92 & 10,41 \\
Bungkil Kelapa & 2,93 & 14,55 & 10,44 \\
Bungkil Kedelai & 4,92 & 13,05 & 7,97 \\
Kapur & 1,75 & 1,64 & 1,77 \\
M Kelapa & 0 & 0 & 3,51 \\
\hline Kandungan : & & & 88 \\
BK (\%) & 87 & 86 & 16,08 \\
PK & 14,26 & 16,23 & 75,79 \\
TDN (\%) & 70,93 & 75,09 & 10,77 \\
SK & 10,89 & 9,4 & 0,95 \\
Ca & 0,96 & 0,96 & 0,96 \\
P & 0,98 & 0,66 & \\
\hline Kete
\end{tabular}

Keterangan: Formulasi menggunakan software WinFeed 2.8. 
Data unsur iklim mikro serta respon suhu rektal, suhu kulit, dan suhu tubuh dianalisis secara deskripsi. Analisis difokuskan pada saat iklim mikro berpotensi mencekam kondisi suhu rektal, suhu kulit, dan suhu tubuh ternak menggunakan analisis Bujur Sangkar Latin. Uji lanjut antar perlakuan menggunakan Uji Tukey dan Kontras Ortogonal.

\section{HASIL DAN PEMBAHASAN}

\section{Kondisi Unsur Cuaca dalam Kandang}

Perubahan-perubahan pada panas lingkungan sangat tergantung dari kondisi udara lingkungan yang meliputi suhu udara, kelembaban udara, kecepatan angin, radiasi matahari, kepadatan kandang, dan juga pada karakter pelepasan panas metabolis tubuh ternak (Berman, 2008). Hasil pengamatan selama penelitian berlangsung dari pukul 05.00 hinggga pukul 20.00, data yang diperoleh menunjukkan kondisi lingkungan iklim mikro kandang penelitian berupa kisaran suhu udara berkisar antara $23,08-31,83^{\circ} \mathrm{C}$, kelembaban udara antara 61,38-89,00\%, nilai THI berkisar antara 72,20-82,36, kecepatan angin antara 0-0,90 m/detik, dan radiasi matahari antara 11,25-737,88 Lux (Tabel 2).

Tabel 2.Rataan suhu udara, kelembaban udara, THI, kecepatan angin, dan radiasi matahari selama Maret-Juni 2012

\begin{tabular}{cllccr}
\hline Pukul $(\mathrm{WIB})$ & $\mathrm{Ta}\left({ }^{\circ} \mathrm{C}\right)$ & $\mathrm{Rh}(\%)$ & $\mathrm{THI}$ & $\mathrm{Va}(\mathrm{m} / \mathrm{detik})$ & \multicolumn{1}{c}{$\mathrm{Rad}(\mathrm{Lux})$} \\
\hline 5 & $23,08 \pm 0,73$ & $89,00 \pm 3,40$ & $72,20 \pm 1,00$ & 0 & $11,25 \pm 28$ \\
6 & $23,58 \pm 0,84$ & $87,75 \pm 5,90$ & $72,83 \pm 1,70$ & 0 & $147,67 \pm 80$ \\
7 & $25,19 \pm 0,76$ & $83,92 \pm 5,90$ & $74,74 \pm 1,10$ & 0 & $419,29 \pm 171$ \\
8 & $27,46 \pm 0,60$ & $73,58 \pm 6,30$ & $77,34 \pm 0,90$ & $0,03 \pm 0,10$ & $577,63 \pm 180$ \\
9 & $28,77 \pm 0,50$ & $71,88 \pm 6,40$ & $78,90 \pm 0,80$ & $0,18 \pm 0,10$ & $649,92 \pm 147$ \\
10 & $30,23 \pm 0,80$ & $67,63 \pm 6,30$ & $80,57 \pm 1,00$ & $0,33 \pm 0,20$ & $702,83 \pm 172$ \\
11 & $31,06 \pm 1,00$ & $65,00 \pm 5,90$ & $81,50 \pm 1,20$ & $0,42 \pm 0,20$ & $737,88 \pm 135$ \\
12 & $31,83 \pm 0,90$ & $62,29 \pm 6,10$ & $82,36 \pm 1,10$ & $0,90 \pm 0,20$ & $730,83 \pm 141$ \\
13 & $31,71 \pm 1,30$ & $61,38 \pm 6,20$ & $82,16 \pm 1,40$ & $0,54 \pm 0,20$ & $707,46 \pm 141$ \\
14 & $30,56 \pm 1,70$ & $66,17 \pm 7,10$ & $80,95 \pm 1,90$ & $0,45 \pm 0,30$ & $614,96 \pm 194$ \\
15 & $29,13 \pm 1,30$ & $71,13 \pm 6,40$ & $79,33 \pm 1,60$ & $0,33 \pm 0,30$ & $416,21 \pm 165$ \\
16 & $27,96 \pm 1,20$ & $75,71 \pm 6,40$ & $78,02 \pm 1,40$ & $0,28 \pm 0,30$ & $232,16 \pm 85$ \\
17 & $27,08 \pm 0,90$ & $77,88 \pm 7,10$ & $77,00 \pm 1,10$ & $0,20 \pm 0,20$ & $110,73 \pm 79$ \\
18 & $26,40 \pm 1,00$ & $80,04 \pm 7,00$ & $76,22 \pm 1,30$ & $0,19 \pm 0,30$ & $36,54 \pm 48$ \\
19 & $25,73 \pm 1,20$ & $83,17 \pm 6,40$ & $75,48 \pm 1,70$ & $0,16 \pm 0,20$ & 0 \\
20 & $25,25 \pm 0,90$ & $85,13 \pm 6,10$ & $74,91 \pm 1,40$ & $0,12 \pm 0,20$ & 0 \\
\hline
\end{tabular}

Nilai suhu dan kelembaban udara tersebut, memperlihatkan kondisi lingkungan ternak berpotensi memberikan cekaman panas pada sapi dara Fries Holland (FH). Kisaran zona termonetral ternak berada pada suhu udara antara 5$25^{\circ} \mathrm{C}$ (Jones dan Stallings, 1999), suhu udara antara $13-25^{\circ} \mathrm{C}$ dan kelembaban udara antara 50-60\% (McNeilly, 2001). Suhu dan kelembaban lingkungan yang ideal bagi penampilan produksi sapi perah peranakan $\mathrm{FH}$ akan dicapai pada suhu udara $18,3^{\circ} \mathrm{C}$ dan kelembaban udara $55 \%$, serta penampilan produksi masih cukup baik bila suhu lingkungan meningkat sampai $21,1^{0} \mathrm{C}$ serta suhu kritis sebesar $27^{0} \mathrm{C}$ (Sudono et al., 2003).

Kondisi siang hari (pukul 10.0015.00), suhu udara, THI dan radiasi matahari meningkat hingga pukul 13.00, 
sebaliknya kelembaban udara menurun, tetapi kelembaban udara tersebut tetap pada nilai yang berpotensi memberikan cekaman panas pada ternak. Bohmanova (2007) menyatakan bahwa kelembaban udara merupakan faktor penghambat proses stress panas pada iklim lembab dan suhu udara kering, serta merupakan faktor pembatas stress panas pada iklim kering. Nilai rataan THI pada pukul 12.00 dan pukul 13.00 adalah yang tertinggi di lokasi penelitian yaitu sebesar 82,36 dan 82,16. Hasil nilai rataan THI tersebut mengindikasikan adanya cekaman panas, hal ini berdasarkan klasifikasi Pennington dan Van Devender (2004) nilai THI tersebut menunjukan terjadinya cekaman panas sedang pada ternak. Cekaman panas sedang ditandai dengan terjadinya pelepasan panas tubuh sebanyak 50\% melalui proses respirasi (Berman,2005).Usaha untuk peningkatan pemahaman efek lingkungan iklim mikro pada siang hari dengan ditandai terjadinya cekaman panas pada ternak menuntut peternak untuk memaksimalkan efek positif dan negatifnya (Coller et al., 2006).

Kecepatan angin berfungsi mengalirkan udara yang bersuhu lebih tinggi di sekitar ternak ke tempat yang lain. Selain itu, angin dapat membantu proses konveksi dan evaporasi panas dari tubuh ternak ke lingkungan. Pada pagi menuju siang hari, kecepatan angin meningkat seiring meningkatnya suhu udara dan radiasi matahari, tetapi peningkatan kecepatan angin belum banyak berpengaruh pada penurunan cekaman panas tubuh ternak. Rataan kecepatan anginsiang hari (pukul 12.00) yaitu 0,90 m/detik belum membantu cekaman panas pada sapi FH. Pemberian kecepatan angin 1,12-1.30 m/detik akan membantu sapi FH mengatasi cekaman panas (Lee dan Keala, 2005).

\section{Konsumsi Pakan dan Pertambahan Bobot Badan}

Selama penelitian berlangsung kebutuhan nutrisi pakan bervariasi antar ternak. Variasi ini muncul dikarenakan adanya perbedaan bobot badan sapi perah dara yang digunakan serta periode lingkungan mikro penelitian. Faktor penting dalam penyusunan ransum dan tingkat konsumsi pakan adalah bobot badan sapi. Tabel 3 menunjukkan rataan tingkat konsumsi bahan kering (BK) ransum serta perubahan pertambahan bobot badan sapi perah dara. Konsumsi BK pakan sapi perah dara berkisar antara 7,0$7,4 \mathrm{~kg}$. Besarnya konsumsi tersebut,masih sesuai dengan anjuran NRC (2001) bahwa sapi dara $\mathrm{FH}$ dengan bobot badan antara $150 \mathrm{~kg}$ dan $300 \mathrm{~kg}$ dengan PBB $0.6 \mathrm{~kg}$ per hari dibutuhkan BK berkisar 4.9kg dan 7.4 $\mathrm{kg}$ per hari. Kondisi cekaman panas, efisiensi penggunaan energi akan berkurang karena meningkatnya energi untuk hidup pokok dan energi untuk aktivitas termoregulasi.

Hasil analisis sidik ragam untuk pertambahan bobot badan tidak menunjukkan perbedaan yang signifikan antar perlakuan energi ransum $(\mathrm{P}<0.05)$. Meskipun demikian, rataan PBB dari perlakuan $\mathrm{E}$ jauh lebih rendah dibanding dari perlakuan lainnya yaitu sebesar 0.55 $\mathrm{kg}$ per hari. Kondisi tersebut disebabkan energi ransum yang tinggi menjadi tambahan panas selain suhu lingkungan, 
sehingga ternak mengurangi konsumsi sebagai akibat menghindari produksi panas atau berfungsinya proses termoregulasi. Pada perlakuan E menyebabkan fungsi tubuh bekerja secara ekstra untuk proses termoregulasi dalam menyeimbangkan produksi dan pengeluaran panas.

Pertambahan bobot badan lebih tinggi pada ternak yang memiliki kecenderungan lebih rendah pada respon fisiologis saat cekaman panas tubuh. Suhu berpengaruh terhadap tingkat metabolisme dan reaksi-reaksi kimia di dalam tubuh termasuk reaksi metabolisme (Tobin, 2005). Kamanga-Sollo et al. (2011) menyatakan pada saat tubuh ternak mengalami cekaman panas, tubuh akan menurunkan laju metabolisme dengan menekan sekresi hormon tiroksin serta mengeluarkan heat shock proteins yang memiliki peranan penting untuk merespon stress panas dan jenis stress seluler lainnya dan dalam tingkat regulasi dan efisiensi perkembangan otot.

Peningkatan beban panas yang disebabkan kombinasi suhu udara, kelembaban relatif, angin, dan radiasi matahari dapat meningkatkan suhu tubuh dan frekuensi respirasi serta mengurangi konsumsi pakan dan produksi susu (Hahn 1999; Ominski et al., 2002; West 2003). Pada saat terjadi cekaman panas tubuh, performa kerja jantung berkurang akibat berkurangnya nutrisi pendukung denyut jantung seperti kalium. Kalium tersebut terbuang pada saat evaporasi untuk mengatasi cekaman panas tubuh.

Tabel 3 Rataan konsumsi BK,TDN, Protein kasar (PK), Lemak Kasar (LK), Serat Kasar (SK) ransum dan PBB sapi perah dara selama perlakuan

\begin{tabular}{|c|c|c|c|c|c|c|}
\hline \multirow[b]{2}{*}{ Peubah } & \multicolumn{5}{|c|}{ Perlakuan } & \multirow[b]{2}{*}{$\mathrm{F}$} \\
\hline & $\mathrm{A}$ & B & $\mathrm{C}$ & $\mathrm{D}$ & $\mathrm{E}$ & \\
\hline Kons BK (kg) & & & & & & \\
\hline Hijauan & $4,2 \pm 1,17$ & $4,0 \pm 0,98$ & $4,3 \pm 0,16$ & $4,1 \pm 0,57$ & $4,1 \pm 0,61$ & $4,1 \pm 0,34$ \\
\hline $\begin{array}{l}\text { Konsentrat } \\
\text { Kons TDN (kg) }\end{array}$ & $3,2 \pm 1,17$ & $3,3 \pm 0,98$ & $3,0 \pm 0,84$ & $2,9 \pm 0,96$ & $2,9 \pm 0,84$ & $2,9 \pm 0,88$ \\
\hline Hijauan & $2,4 \pm 0,49$ & $2,3 \pm 0,43$ & $2,5 \pm 0,05$ & $2,3 \pm 0,23$ & $2,3 \pm 0,44$ & $2,3 \pm 0,26$ \\
\hline $\begin{array}{l}\text { Konsentrat } \\
\text { Kons PK (kg) }\end{array}$ & $1,8 \pm 0,64$ & $1,9 \pm 0,58$ & $1,9 \pm 0,55$ & $2,0 \pm 0,68$ & $2,0 \pm 0,56$ & $2,0 \pm 0,68$ \\
\hline Hijauan & $0,33 \pm 0,06$ & $0,34 \pm 0,08$ & $0,36 \pm 0,01$ & $0,34 \pm 0,01$ & $0,34 \pm 0,06$ & $0,35 \pm 0,07$ \\
\hline $\begin{array}{l}\text { Konsentrat } \\
\text { Kons LK (kg) }\end{array}$ & $0,37 \pm 0,08$ & $0,37 \pm 0,09$ & $0,40 \pm 0,01$ & $0,39 \pm 0,01$ & $0,39 \pm 0,02$ & $0,39 \pm 0,03$ \\
\hline Hijauan & $0,05 \pm 0,01$ & $0,05 \pm 0,01$ & $0,05 \pm 0,01$ & $0,05 \pm 0,01$ & $0,05 \pm 0,01$ & $0,05 \pm 0,01$ \\
\hline $\begin{array}{l}\text { Konsentrat } \\
\text { Kons SK (kg) }\end{array}$ & $0,2 \pm 0,07^{\mathrm{a}}$ & $0,19 \pm 0,06^{\mathrm{ab}}$ & $0,21 \pm 0,07^{\mathrm{b}}$ & $0,20 \pm 0,05^{\mathrm{a}}$ & $0,19 \pm 0,07^{\mathrm{ab}}$ & $0,20 \pm 0,05^{\mathrm{a}}$ \\
\hline Hijauan & $1,6 \pm 0,45$ & $1,5 \pm 0,38$ & $1,6 \pm 0,06$ & $1,5 \pm 0,22$ & $1,5 \pm 0,15$ & $1,5 \pm 0,17$ \\
\hline Konsentrat & $0,4 \pm 0,14^{\mathrm{b}}$ & $0,38 \pm 0,11^{\mathrm{b}}$ & $0,30 \pm 0,08^{\mathrm{a}}$ & $0,30 \pm 0,08^{\mathrm{a}}$ & $0,32 \pm 0,07^{\mathrm{a}}$ & $0,34 \pm 0,1^{\mathrm{a}} 1$ \\
\hline PBB (kg) & $0,63 \pm 0,08^{\mathrm{ab}}$ & $0,65 \pm 0,05^{\mathrm{ab}}$ & $0,68 \pm 0,06^{\mathrm{b}}$ & $0,63 \pm 0,08^{\mathrm{ab}}$ & $0,55 \pm 0,08^{\mathrm{a}}$ & $0,63 \pm 0,08^{\mathrm{ab}}$ \\
\hline
\end{tabular}

Keterangan: P1R1 (A), P1R2 (B), P1R3 (C), P2R1 (D), P2R2 (E), dan P2R3 (F). Superskrip berbeda pada baris yang sama menunjukkan perbedaan yang nyata antar perlakuan $(\mathrm{P}<0.05)$.

\section{Respon Suhu Rektal}

Hasil pengukuran suhu rektal harian ternak berkisar antara $38,5-39,2^{\circ} \mathrm{C}$. Kisaran suhu rektal normal untuk sapi perah antara $38,2-39,1^{\circ} \mathrm{C}$ (Schutz et al., 2009). Suhu rektal terendah terjadi pada pukul $05.00 \quad\left(38,5^{\circ} \mathrm{C}\right)$ dan meningkat setelah ternak mengkonsumsi pakan serta seiring meningkatnya suhu udara. Suhu rektal ternak yang diberi pakan pukul 05.00 pagi, cenderung lebih rendah saat ada peningkatan suhu udara siang hari 
(pukul 10.00-15.00) dibanding yang diberi pakan pukul 08.00 pagi (Gambar 1). Hasil penelitian Wheelock et al. (2010) melaporkan bahwa suhu rektal meningkat selama cekaman panas $\left(40,4^{0} \mathrm{C}\right)$ dan dapat mengurangi konsumsi bahan kering sebanyak $30 \%$.

Suhu rektal tertinggi terjadi sore hari pukul $17.00\left(39,2^{\circ} \mathrm{C}\right)$ pada ternak yang diberi pakan sore pukul 16.00 dan malam hari pukul $19.00\left(39,1^{\circ} \mathrm{C}\right)$ pada ternak yang diberi pakan sore pukul 18.00.Peningkatan suhu rektal tersebut diakibatkan adanya peningkatan panas metabolis tubuh, karena ternak baru mengkonsumsi pakan pada pukul 16.00 dan 18.00, dan adanya proses homeostasis ternak setelah terjadi gangguan homeostasis pada siang hari (pukul 10.00-15.00).

Berdasarkan pada Gambar 1, suhu rektal ternak masih dalam kisaran normal pada siang hari, termasuk pada pukul 12.00 dan pukul 13.00 saat suhu udara dan cekaman panas tertinggi, suhu rektal masih berkisar antara $38,7-39,0^{\circ} \mathrm{C}$. Perlakuan pemberian pakan pukul 05.00 dapat memberi efek pada suhu rektal yang lebih rendah saat ada cekaman cuaca panas siang dibanding perlakuan pemberian minyak kelapa dalam konsentrat.

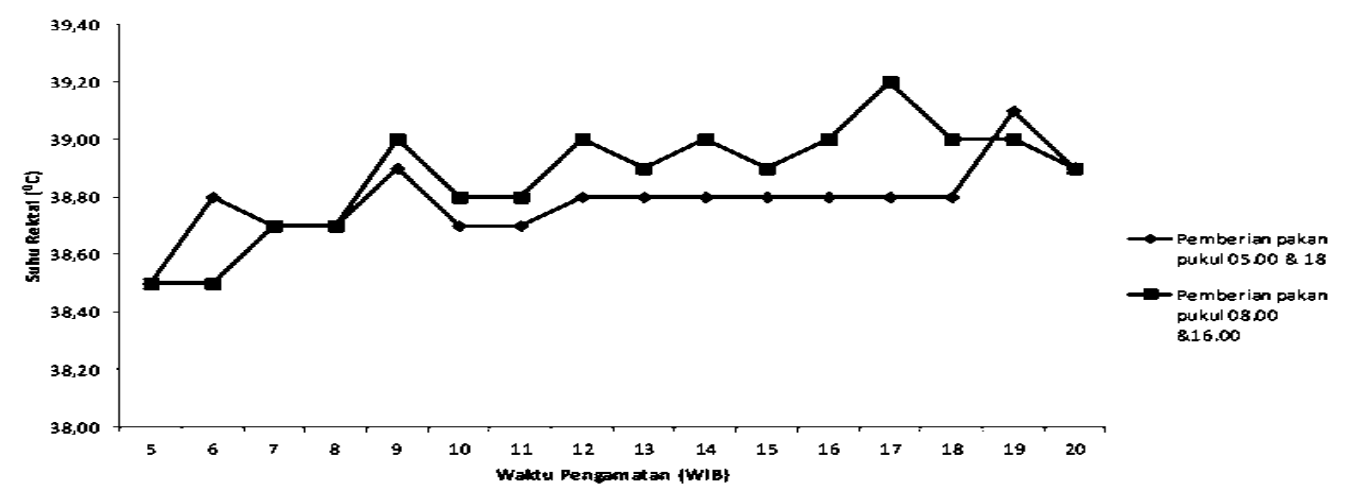

Gambar 1. Fluktuasi rataan suhu rektal ternak yang diberi pakan pukul 05.00 dan 18.00 WIB dan 08.00 dan 16.00 WIB.

Hasil analisis pada pukul 12.00, ternak yang diberi pakan lebih awal (pukul 05.00 pagi), rataan suhu rektalnya lebih rendah $(\mathrm{P}<0.05)$ dibanding ternak yang diberi pakan pada pukul 08.00 (Tabel 4). Hal tersebut dapat disebabkan beban panas tubuh yang lebih rendah pada ternak yang mengkonsumsi pakan pagi pukul 05.00.

Tabel 4 Rataan suhu rektal ternak pada siang hari $\left({ }^{0} \mathrm{C}\right)$

\begin{tabular}{ccccccc}
\hline \multirow{2}{*}{$\begin{array}{c}\text { Pukul } \\
\text { (WIB) }\end{array}$} & \multicolumn{5}{c}{ Perlakuan } \\
\cline { 2 - 7 } & $\mathrm{A}$ & $\mathrm{B}$ & $\mathrm{C}$ & $\mathrm{D}$ & $\mathrm{E}$ & $\mathrm{F}$ \\
\hline 10 & $38,6 \pm 0,1^{\mathrm{a}}$ & $38,8 \pm 0,4^{\mathrm{a}}$ & $38,8 \pm 0,4^{\mathrm{a}}$ & $38,8 \pm 0,3^{\mathrm{a}}$ & $38,9 \pm 0,4^{\mathrm{a}}$ & $38,8 \pm 0,3^{\mathrm{a}}$ \\
11 & $38,6 \pm 0,2^{\mathrm{a}}$ & $38,7 \pm 0,2^{\mathrm{a}}$ & $38,9 \pm 0,3^{\mathrm{a}}$ & $38,8 \pm 0,3^{\mathrm{a}}$ & $38,9 \pm 0,4^{\mathrm{a}}$ & $38,8 \pm 0,2^{\mathrm{a}}$ \\
12 & $38,7 \pm 0,6^{\mathrm{a}}$ & $38,8 \pm 0,4^{\mathrm{a}}$ & $38,8 \pm 0,6^{\mathrm{ab}}$ & $39 \pm 0,8^{\mathrm{ab}}$ & $39,1 \pm 0,6^{\mathrm{b}}$ & $39 \pm 0,7^{\mathrm{ab}}$ \\
13 & $38,8 \pm 0,2^{\mathrm{a}}$ & $38,8 \pm 0,3^{\mathrm{a}}$ & $38,9 \pm 0,3^{\mathrm{ab}}$ & $39 \pm 0,3^{\mathrm{ab}}$ & $38,9 \pm 0,4^{\mathrm{ab}}$ & $39 \pm 0,2^{\mathrm{b}}$ \\
14 & $38,7 \pm 0,3^{\mathrm{a}}$ & $38,8 \pm 0,3^{\mathrm{a}}$ & $39 \pm 0,4^{\mathrm{a}}$ & $39 \pm 0,3^{\mathrm{a}}$ & $39 \pm 0,5^{\mathrm{a}}$ & $39 \pm 0,3^{\mathrm{a}}$ \\
15 & $38,7 \pm 0,3^{\mathrm{a}}$ & $38,8 \pm 0,2^{\mathrm{a}}$ & $38,8 \pm 0,2^{\mathrm{a}}$ & $38,9 \pm 0,3^{\mathrm{a}}$ & $39 \pm 0,4^{\mathrm{a}}$ & $38,8 \pm 0,2^{\mathrm{a}}$
\end{tabular}

Keterangan : P1R1 (A), P1R2 (B), P1R3 (C), P2R1 (D), P2R2 (E), dan P2R3 (F). Superskrip berbeda pada baris yang sama menunjukkan perbedaan yang nyata antar perlakuan $(\mathrm{P}<0.05)$. 
Pada pemberian pakan pukul 05.00 mengakibatkan puncak beban panas dari hasil metabolisme pakan dan unsur-unsur iklim lingkungan tidak terjadi bersamaan, sehingga panas tubuh termasuk rektal jadi relatif lebih rendah. Panas hasil metabolisme mempengaruhi fluktuasi seluruh kondisi fisiologis tubuh. Panas tubuh metabolis diedarkan oleh sistem sirkulasi ke seluruh bagian tubuh termasuk organ jantung, respirasi, dan rektal. Berdasarkan hal tersebut, peningkatan denyut jantung akibat beban panas hasil metabolisme relatif seirama dengan peningkatan frekuensi respirasi dan suhu rektal.

Ternak yang mengkonsumsi konsentrat mengandung minyak kelapa $3,5 \%$ menunjukkan tidak berbeda nyata ( $>0.05)$ pada suhu rektal dengan ternak yang mengkonsumsi konsentrat tanpa mengandung minyak kelapa.Hasil penelitian Moallem (2010) melaporkan bahwa perlakuan sebanyak $1,5 \%$ dari total bahan pakan cukup efektif untuk mengurangi produksi panas metabolis, meskipun demikian perubahan pada suhu rektal dan frekuensi respirasi tidak terdeteksi.

Suhu rektal kurang dipengaruhi kandungan pakan, diduga disebabkan suhu rektal lebih dipengaruhi unsur-unsur cuaca lingkungan. Kadzere et al. (2002) mengemukakan bahwa penyesuaian kondisi fisiologis dapat menyebabkan produksi panas yang berlebihan. Cekaman panas menyebabkan keseimbangan energi negatif (Boonkum et al., 2011). Selanjutnya keseimbangan energi negatif dapat mengakibatkan kondisi fisiologis, begitu juga produktivitas yang negatif.

\section{Respon Suhu Kulit}

Suhu permukaan kulit harian ternak berkisar antara $29,0-34,20^{\circ} \mathrm{C}$. Suhu kulit sapi yang dipelihara dalam lingkungan mikro yang nyaman berkisar antara 33,5$37,1^{0} \mathrm{C}$ (Tucker et al., 2008). Pada pagi pukul 05.00, suhu permukaan kulit terendah $\left(29^{\circ} \mathrm{C}\right)$ yang terjadi pada ternak dengan waktu pemberian pakan pada pukul 08.00. Suhu permukaan kulit tertinggi pada pukul 12 siang $\left(34,2^{\circ} \mathrm{C}\right)$ terjadi pada ternak baik dengan waktu pemberian pakan pukul 05.00 maupun waktu pemberian pakan 08.00 dan menggunakan konsentrat berkadar TDN $70 \%$ dan $75 \%$ (Gambar 2).Kulit mempunyai hubungan dengan fluktuasi unsur iklim karena mengalami kontak langsung dengan cuaca. Marcilac (2009) mengemukakan bahwa suhu permukaan tubuh bervariasi berdasarkan kadar uap air lingkungan, lokasi kandang (naungan), dan ventilasi. 


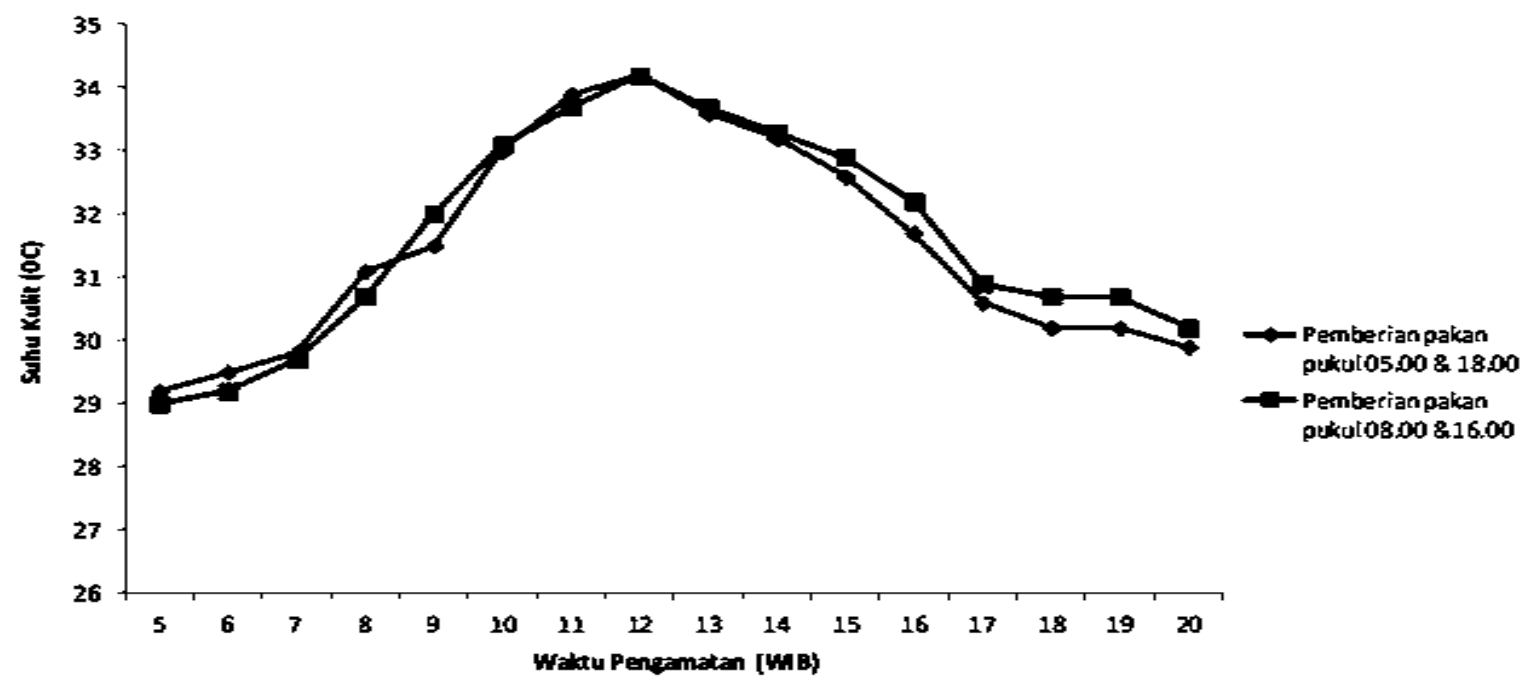

Gambar 2 Fluktuasi rataan suhu permukaan kulit ternak yang diberi pakan pukul 05.00 dan 18.00 WIB dan 08.00 dan 16.00 WIB.

Kulit merupakan tempat pembuangan panas yang utama melalui proses radiasi, konveksi, konduksi, dan evaporasi. Saat cuaca lingkungan berpotensi memberikan cekaman panas pada tubuh ternak serta THI lingkungan mikro tertinggi pada siang hari (pukul 12.00), ternak yang mengkonsumsi pakan pukul 05.00, rataan suhu permukaan kulitnya cenderung lebih rendah $(\mathrm{P}<0.05)$ dibanding suhu permukaan kulit ternak yang mengkonsumsi pakan pada pukul 08.00 (Tabel 5). Hal tersebut diduga diakibatkan oleh energi panas pada kulit relatif lebih rendah pada ternak yang mengkonsumsi pakan pukul 05.00 dibanding ternak yang mengkonsumsi pakan pada pukul 08.00.

Menurunnya intensitas vasokontriksi pheripheral dapat meningkatkan konduksi panas dari inti tubuh ke kulit dan mengurangi terjadinya puncak hyperthermia (Berman ,2010). Jumlah panas yang hilang dari tubuh dalam batas-batas yang luas di atur oleh perubahan jumlah darah yang mengalir melalui kulit. Proses pelepasan panas melalui kulit terjadi melalui mekanisme vasodilatasi, yaitu pembuluh darah mengembang untuk berdekatan dengan kulit pada lingkungan luar yang memungkinkan panas dibebaskan keluar.

Tabel 5 Rataan suhu permukaan kulit ternak pada siang hari $\left({ }^{0} \mathrm{C}\right)$

\begin{tabular}{ccccccc}
\hline $\begin{array}{c}\text { Pukul } \\
\text { (WIB) }\end{array}$ & \multicolumn{5}{c}{ Perlakuan } \\
\cline { 2 - 7 } & $\mathrm{A}$ & $\mathrm{B}$ & $\mathrm{C}$ & $\mathrm{D}$ & $\mathrm{E}$ & $\mathrm{F}$ \\
\hline 10 & $32,9 \pm 1,1^{\mathrm{a}}$ & $32,7 \pm 1,5^{\mathrm{a}}$ & $32,6 \pm 1,4^{\mathrm{a}}$ & $32,6 \pm 0,9^{\mathrm{a}}$ & $33,4 \pm 1,1^{\mathrm{a}}$ & $32,7 \pm 1,1^{\mathrm{a}}$ \\
11 & $33,1 \pm 1,7^{\mathrm{a}}$ & $33,3 \pm 1^{\mathrm{a}}$ & $33,5 \pm 1,5^{\mathrm{a}}$ & $33,3 \pm 1,4^{\mathrm{a}}$ & $33,2 \pm 1,8^{\mathrm{a}}$ & $33,3 \pm 1,5^{\mathrm{a}}$ \\
12 & $33,9 \pm 0,1^{\mathrm{a}}$ & $33,9 \pm 0,1^{\mathrm{a}}$ & $33,7 \pm 0,1^{\mathrm{a}}$ & $33,7 \pm 0,1^{\mathrm{a}}$ & $34,2 \pm 0,2^{\mathrm{a}}$ & $33,7 \pm 0,1^{\mathrm{a}}$ \\
13 & $33,1 \pm 1,1^{\mathrm{a}}$ & $33,5 \pm 0,7^{\mathrm{a}}$ & $33,6 \pm 1,1^{\mathrm{a}}$ & $33,3 \pm 1,8^{\mathrm{a}}$ & $33,9 \pm 0,8^{\mathrm{a}}$ & $33,9 \pm 1,3^{\mathrm{a}}$ \\
14 & $32,5 \pm 1,8^{\mathrm{a}}$ & $32,9 \pm 1,2^{\mathrm{a}}$ & $33,1 \pm 1,6^{\mathrm{a}}$ & $32,4 \pm 1,9^{\mathrm{a}}$ & $32,9 \pm 1,7^{\mathrm{a}}$ & $33 \pm 1,7^{\mathrm{a}}$ \\
15 & $32,1 \pm 1,6^{\mathrm{a}}$ & $31,9 \pm 1,1^{\mathrm{a}}$ & $32 \pm 1,6^{\mathrm{a}}$ & $31,3 \pm 1,5^{\mathrm{a}}$ & $32,4 \pm 1,6^{\mathrm{a}}$ & $32,3 \pm 1,9^{\mathrm{a}}$ \\
\hline
\end{tabular}

Keterangan: P1R1 (A), P1R2 (B), P1R3 (C), P2R1 (D), P2R2 (E), dan P2R3 (F). Superskrip berbeda pada baris yang sama menunjukkan perbedaan yang nyata antar perlakuan $(\mathrm{P}<0.05)$. 


\section{Respon Suhu Tubuh}

Hasil penelitian menunjukkan suhu tubuh harian berkisar antara $37,20-38,4^{\circ} \mathrm{C}$. Ternak diberi pakan pukul 05.00 menunjukkan suhu tubuhnya cenderung lebih rendah pada saat ada peningkatan cekaman panas lingkungan dibanding dengan pemberian pakan pukul 08.00
(Gambar 3). Berdasarkan hal tersebut, pemberian pakan lebih awal cukup sesuai diterapkan untuk menjaga kestabilan suhu tubuh pada lingkungan berpotensi memberikan cekaman panas. Isnaeni (2006) mengemukakan bahwa suhu tubuh pada kebanyakan hewan dipengaruhi suhu lingkungannya.

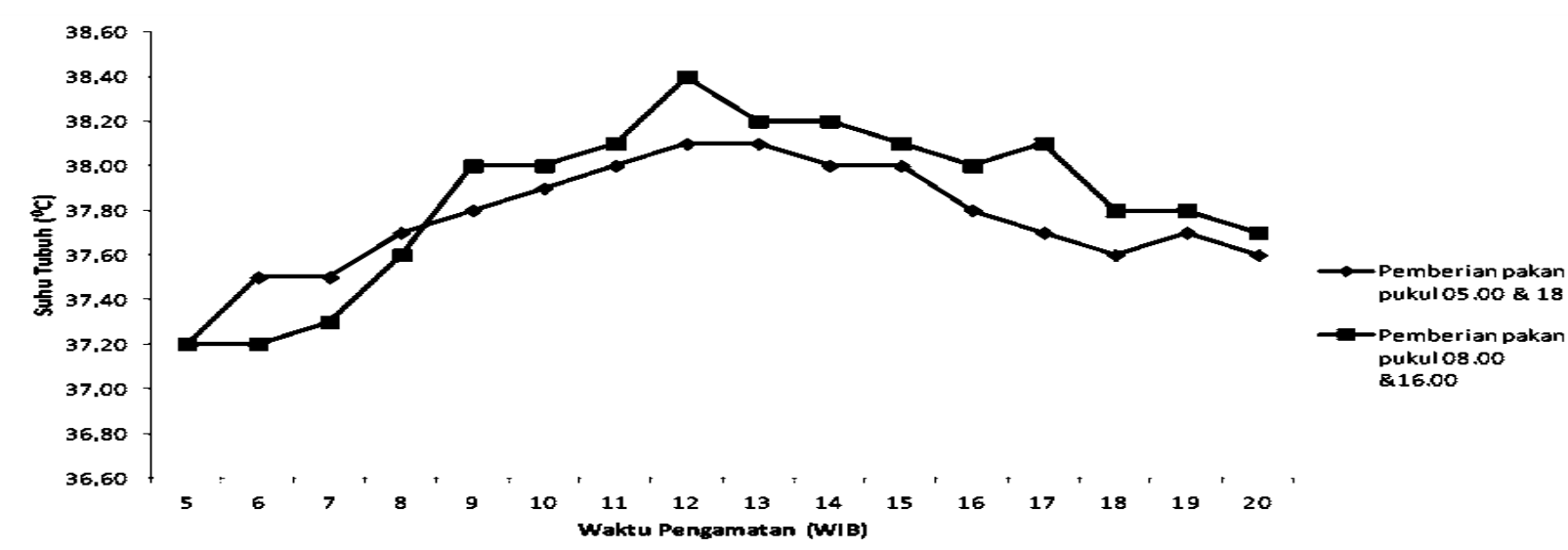

Gambar 3 Fluktuasi rataan suhu tubuh ternak yang diberi pakan pukul $05.00 \& 18.00$ WIB dan pukul $08.00 \& 16.00$ WIB.

Suhu tubuh ternak pada siang hari berkisar antara $37,90-38,4^{\circ} \mathrm{C}$. Nilai kisaran tersebut masih berada pada kisaran normal antara 38,30-38,60 $\mathrm{C}($ Schutz et al. 2008). Suhu tubuh ternak cenderung lebih rendah pada ternak yang diberi pakan pukul 05.00 dan konsentrat TDN $75 \%$ dengan penggunaan minyak kelapa $3,5 \%$ dibanding ternak yang diberi pakan pukul 08.00. Hasil analisis menunjukkan bahwa ternak diberi pakan pukul 05.00 pagi juga memiliki suhu tubuh lebih rendah $(\mathrm{P}<0.01)$ dibanding diberi pakan pukul 08.00 (Tabel 6). Nilai maksimal energi total lebih rendah pada ternak diberi pakan saat hari gelap dibanding saat lebih terang (Brosh dan Aharoni, 2001). Kondisi ternak lebih stabil bila suhu tubuh optimal dan terjadi keseimbangan energi.

Tabel 6. Rataan suhu tubuh ternak pada siang hari $\left({ }^{0} \mathrm{C}\right)$

\begin{tabular}{ccccccc}
\hline Pukul & \multicolumn{7}{c}{ Perlakuan } \\
\cline { 2 - 7 }$($ WIB $)$ & $\mathrm{A}$ & $\mathrm{B}$ & $\mathrm{C}$ & $\mathrm{D}$ & $\mathrm{E}$ & $\mathrm{F}$ \\
\hline 10 & $37,8 \pm 0,2^{\mathrm{a}}$ & $37,9 \pm 0,3^{\mathrm{a}}$ & $37,9 \pm 0,4^{\mathrm{a}}$ & $37,9 \pm 0,4^{\mathrm{a}}$ & $38,1 \pm 0,4^{\mathrm{a}}$ & $38 \pm 0,2^{\mathrm{a}}$ \\
11 & $37,9 \pm 0,4^{\mathrm{a}}$ & $38 \pm 0,2^{\mathrm{a}}$ & $38,1 \pm 0,3^{\mathrm{a}}$ & $38 \pm 0,4^{\mathrm{a}}$ & $38,1 \pm 0,5^{\mathrm{a}}$ & $38,1 \pm 0,2^{\mathrm{a}}$ \\
12 & $38,1 \pm 0,1^{\mathrm{a}}$ & $38,1 \pm 0,1^{\mathrm{a}}$ & $38,1 \pm 0,1^{\mathrm{a}}$ & $38,2 \pm 0,1^{\mathrm{ab}}$ & $38,4 \pm 0,4^{\mathrm{b}}$ & $38,3 \pm 0,1^{\mathrm{ab}}$ \\
13 & $38 \pm 0,2^{\mathrm{a}}$ & $38 \pm 0,4^{\mathrm{a}}$ & $38,2 \pm 0,4^{\mathrm{ab}}$ & $38,2 \pm 0,4^{\mathrm{ab}}$ & $38,2 \pm 0,4^{\mathrm{ab}}$ & $38,3 \pm 0,3^{\mathrm{b}}$ \\
14 & $37,8 \pm 0,5^{\mathrm{a}}$ & $38 \pm 0,4^{\mathrm{a}}$ & $38,1 \pm 0,4^{\mathrm{a}}$ & $38 \pm 0,5^{\mathrm{a}}$ & $38,1 \pm 0,7^{\mathrm{a}}$ & $38,2 \pm 0,3^{\mathrm{a}}$ \\
15 & $37,9 \pm 0^{\mathrm{a}}$ & $37,8 \pm 0^{\mathrm{a}}$ & $37,9 \pm 0^{\mathrm{a}}$ & $37,8 \pm 0^{\mathrm{a}}$ & $38,1 \pm 0^{\mathrm{a}}$ & $37,9 \pm 0^{\mathrm{a}}$
\end{tabular}

Superskrip berbeda pada baris yang sama menunjukkan perbedaan yang nyata antar perlakuan $(\mathrm{P}>0.05)$

Ket : P1R1 (A), P1R2 (B), P1R3 (C), P2R1 (D), P2R2 (E), dan P2R3 (F). 


\section{SIMPULAN}

Respon suhu rektal, suhu kulit, dan suhu tubuh lebih rendah pada sapi dara Fries Holland yang diberi pakan pukul 0.500 dan 18.00 dibanding diberi pakan pukul 08.00 dan 16.00. Pemberian pakan pukul 05.00 dan 18.00 atau penggunaan minyak kelapa sebanyak $3,5 \%$ dalam konsentrat dapat mereduksi beban panas tubuh sapi dara Fries Holland.

\section{DAFTAR PUSTAKA}

Berman, A. 2005. Estimates of heat stress relief needs for Holstein dairy cows. J Anim Sci 83: 1377-1384.

Berman, A. 2008. Increasing heat stress relief produced by coupled coat wetting and forced ventilation. $\mathbf{J}$ Dairy Sci 91: 4571-4578.

Berman, A. 2010. Forced heat loss from body surface heat flow to body surface. J Dairy Sci 93:242-248.

Bohmanova, J., I. Misztal, and J.B. Cole. 2007. Temperature-humidity indices as indicators of milk production losses due to heat stress. J Dairy Sci 90: 1947-1956.

Boonkum, J., A. Berman, J.B. Cole, and J. Bond. 2011. Short communication: Genetic effects of heat stress on milk yield of Thai Holstein crossbreds. J Dairy Sci 94: 487-492.

Brosh, A. and Y. Aharoni. 2001. Effects of feeding regimen on the diurnal pattern of heat production by dairy cows in hot climate, and on their feed intake and milk yield. In:
Energy Metabolism in Animals. Proceedings of the Symposium on energy Metabolism in Animal; Snekkersten, 11-16 Sept. 2000. Wageningan Press. Pp: 97-100.

Collier, R.J., G.E. Dahl, and M.J. VanBaale. 2006. Major advances associated with environmental effects on dairy cattle. J Dairy Sci 89: 1244-1253.

Hahn, G.L. 1985. Management and Housing of Farm Animal in Hot Environment. In:Stress Phisiology of Livestock. Vol. I. MK Yousef (Ed). CRC Press, Inc. Boca Raton, Florida. Pp: 159-168.

Hahn, G.L. 1999. Dynamic responses of cattle to thermal heat loads. J Anim Sci 77: 10-20.

Isnaeni, W. 2006. Fisiologi Hewan. Penerbit Kanisius: Yogyakarta.

Jones, G.M and C.C. Stallings. 1999. Reducing heat stress for dairy cattle. Virginia Cooperative Extension. Publication Number 404-420.

http://www.ext.edu/index.html. [21 Oktober 2005].

Kadzere, C.T., M.R. Murphy, N. Silanikone, and E. Maltz. 2002. Heat stress in lactating dairy cows: a review. Livestock Prod Sci 77: 59-91.

Kamanga-Sollo, E., A. Berman, M.S. Allen, and J.P. Wang 2011. Effects of heat stress on proliferation, protein turnover, and abundance of heat shock protein messenger ribonucleic acid in cultured porcine 
muscle satellite cells. J Anim Sci 89: 3473-3480.

Lee, C.N. and N. Keala. 2005. Evalution of cooling system to improve lactating Holstein cows comfort in the subtropics. J Anim Sci 82: 128-136.

Marcilac-Emberston, N.M.,

A.D. Kennedy, KM Wittenberg, and SA Moshtaghi-Nia. 2009. Effect of shade and sprinklers on performance, behavior, physiology, and the environment of heifers. $\mathrm{J}$ Dairy Sci 92: 506-517.

McLean, J.A., A.J. Downie, C.D.R. Jones, D.P. Stombough, and C.A. Glasbey. $\quad 1983 . \quad$ Thermal adjustments of stress (Bos taurus) to abrupt changes in environments temperature. Com J Agric Sci 48:81-84.

McNeilly, A.S. 2001. Reproduction, fertility, and development. CSIRO Publishing 13:583-590.

Moallem, U., G. Altmark, H. Lehrer, and A. Arieli. 2010. Performance of high-yielding dairy cows supplemented with fat or concentrate under hot and humid climates. J Dairy Sci 93: 31923202 .

[NRC]. National Research Council. 2001. Nutrient Requirement of Dairy Cattle. $7^{\text {th }}$ revised edition. National Academy Press.

Ominski, K.H., A.D. Kennedy, K.M. Wittenberg, S.A. and MoshtaghiNia. 2002. Physiological and production responses to feeding schedule in lactating dairy cows exposed to short-term, moderate heat stress. J Dairy Sci 85:730-737.

Pennington, J.A. and KVanDevender. 2004. Heat Stress in Dairy Cattle. http://www.uaex.edu/other areas/publication/html $\quad[19$ Mei 2004].

Purwanto, B.P., T. Matsumoto, F. Nakamasu, T. Ito and S. Yamamoto . 1993 ${ }^{\mathrm{a}}$. Effect of standing and lying behaviours on heat production of dairy heifers differing in feed intake levels. AJAS 6:271-274.

Purwanto, B.P., F. Nakamasu, and S. Yamamoto. 1993 ${ }^{b}$. Effect of environmental temperatures on heat production in dairy heifers differing in feed intake level. AJAS. $6: 275$ 279.

Schutz, K.E, N.R. Cox, and L.R. Matthews. 2008. How important is shade to dairy cattle? Choice between shade or lying following different levels of lying deprivation. Appl Anim Behav Sci 114:307-318.

Schutz, K.E., A.R. Rogers, N.R. Cox NR, and C.B. Tucker. 2009. Dairy cows prefer shade that offers greater protection against solar radiation in summer: shade use, behavior, and body temperature. Appl Anim Behav Sci 116:28-34.

Sudono, A., R.F. Rosdiana, and B.S. Setiawan. 2003. Beternak Sapi Perah secara Intensif. Cetakan ke-2. AgroMedia Pustaka, Bogor.

Tobin, A.J. 2005. Asking About Life. Canada: Thomson Brooks. 
Tucker, C.B., A.R. Rogers, and K.E. Wheclock, J.B., H. Lehrer, A. Arieli, and Schutz. 2008. Effect of solar J.B. Cole. 2010. Effects of heat radiation on dairy cattle behaviuor, stress on energetic metabolism in use of shade and body temperature in lactating Holstein cows. J Dairy Sci a pasture-based system. Appl Anim 93: 644-655. Behav Sci 109:141-154.

West, J.W. 2003. Effects of heat stress on production in dairy cattle. J Dairy Sci 86: 2131-2141. 